\title{
Solar Energy Potentials and Benefits in the Gulf Cooperation Council Countries: A Review of Substantial Issues
}

\author{
Abdullahi Abubakar Mas'ud ${ }^{1, *}$, Asan Vernyuy Wirba ${ }^{2}$, Saud J. Alshammari ${ }^{3}$, \\ Firdaus Muhammad-Sukki ${ }^{4}$ (D), Mu'azu Mohammed Abdullahi ${ }^{5}$ (D), Ricardo Albarracín 6 (D) \\ and Mohammed Ziaul Hoq ${ }^{2}$ \\ 1 Department of Electrical and Electronics Engineering, Jubail Industrial College, P.O. Box 10099, \\ Jubail Industrial City 31261, Saudi Arabia \\ 2 Department of Management and Information Technology, Jubail Industrial College, P.O. Box 10099, \\ Jubail Industrial City 31261, Saudi Arabia; asan_v@jic.edu.sa (A.V.W.); mohammad_z@jic.edu.sa(M.Z.H.) \\ 3 Department of Electrical and Electronic Engineering, University of Sheffield, Western Bank, \\ Sheffield S10 2TN, UK; salshammari1@sheffield.ac.uk \\ 4 School of Engineering, Robert Gordon University, Garthdee Road, Aberdeen AB10 7GJ, Scotland, UK; \\ f.b.muhammad-sukki@rgu.ac.uk \\ 5 Department of Civil Engineering, Jubail University College, P.O. Box 10074, Jubail Industrial City 31261, \\ Saudi Arabia; mmuazuabdulahi@gmail.com \\ 6 Departamento de Ingeniería Eléctrica, Electrónica, Automática y Física Aplicada, Escuela Técnica Superior \\ de Ingeniería y Diseño Industrial, Universidad Politécnica de Madrid, Ronda de Valencia 3, 28012 Madrid, \\ Spain; rasbarracin@gmail.com \\ * Correspondence: abdullahi.masud@gmail.com; Tel.: +966-053-813-8814
}

Received: 27 November 2017; Accepted: 20 January 2018; Published: 5 February 2018

\begin{abstract}
It is a well-known fact that the fossil fuel industry has dominated the economy of the Gulf Cooperation Council (GCC) countries during the last few decades. However, recent developments show that most of the GCC countries plan to increase the share of renewable energy (RE) in their future electrical power production. To ensure realistic increase in the share of RE in the production of electricity in the future, firm policies must be laid down with the objective to promote and market the benefit of RE to their citizens. Due to the high-solar radiation in the GCC region, the focus is now on solar energy development. This paper presents an up-to-date review of the progress made on solar energy in the GCC together with the challenges and the way forward. Some of the challenges and barriers hindering the development of RE in the GCC are in the area of technological know-how, policy development, and insufficient application of RE technology integrated in the buildings among others. Areas of improvement include promoting research and development, public/private initiatives, legislation and regulatory framework, solutions to technical issues and exchange of knowledge, scientific advice, and last but not the least is the issue of building integration with RE.
\end{abstract}

Keywords: renewable energy; solar energy; GCC

\section{Introduction}

The Gulf Cooperation Council (GCC) countries comprise Bahrain, Kuwait, Oman, Qatar, Saudi Arabia and the United Arab Emirates (UAE). About $66 \%$ of the global oil reserves are situated in the Arabian Gulf [1]. The world is currently experiencing a decrease in the oil prices since 2015. This oil slump will greatly affect the GCC countries because they are the major exporters of oil in the world. These countries export revenues and gross domestic product (GDP) will slump and this will lead to 
their current budget deficits. It is a well-known fact that the GCC countries depend on oil as the major energy source, especially for power generation, which is non-renewable. The environmental impact from non-renewable energy (RE) sources such as gas and oil are enormous and can cause a major challenge for these countries. For example, an increase in high-carbon dioxide $\left(\mathrm{CO}_{2}\right)$ emissions that pollute the atmosphere and subsequently affect global warming [2]. The oil installations / constructions (coastal and off-shore) have even major impacts on the environment. Besides, off-shore oil rigs kills sea birds at night due to lightning and flares. There is also a carbon release from burning of oil because of the flaring process. Additionally, birds and other marine animals get killed as a result of oil ingestion [3]. Therefore, there is an urgent need for the GCC countries to consider RE sources in their energy mix. RE potentials are enormous in the GCC countries, especially solar [4] that are not currently being fully utilized. Annual average solar radiation within the GCC countries is relatively equal to 1.1 barrel of oil equivalent per $\mathrm{m}^{2}$. The radiation is the highest in Kuwait, in June-July, $\left(8200 \mathrm{kWh} / \mathrm{m}^{2}\right)$ and the lowest in Oman $\left(6400 \mathrm{kWh} / \mathrm{m}^{2}\right)$. The radiation is low in January-December $\left(4200 \mathrm{kWh} / \mathrm{m}^{2}\right.$ in the UAE and $3200 \mathrm{kWh} / \mathrm{m}^{2}$ in Bahrain) [5].

Solar energy is regarded as infinite in the long-term and is an ample RE resource available within the GCC countries [6]. The two most renowned solar energy technologies are the solar thermal system and solar photovoltaic (PV) system [2]. It is well-known that solar PV produces electricity from sunlight through an electronic mechanism in a specific type of semiconductor material, commonly silicon. The sunrays induce free electrons from these materials to travel in an electrical circuit in order to power electrical systems or conveying the electricity to the grid. The PV panels can be installed on the ground, on rooftops or standing structures. On the other hand, the solar thermal technology generates heat for heating fluids or water and for powering solar cooling systems [7]. Since, in most countries of the world solar PV is the most commonly used, this paper will focus on the solar PV.

The solar PV can contribute immensely to the socio-economic development of the GCC region. According to an International Renewable Energy Agency (IRENA) report [8], the GCC countries could gain numerous benefits from RE implementation. These include oil savings of about 400 billion barrels and creating 210,000 jobs by the year 2030. A recent report from the Gulf Research Center in the UAE shows the assessment index for GCC countries based on their RE index, where Saudi Arabia and UAE are ahead of other GCC countries regarding RE adoption, but in terms of launching new projects, the UAE is leading with several solar power projects [9].

The RE sector within the GCC countries is considered to be at an early stage, but recently plans and aspirations are gradually transforming into projects with the long-term outlook looking auspicious. There is a likely future acceleration of RE as up to $250 \mathrm{MW}$ projects are on the way [10]. Investment in RE among the GCC countries rises in 2011 with slightly over USD 800 million, but later dropped to less than USD 100 million in 2012 [8]. Nevertheless, as at 2015, investments in new projects rose to around USD 900 million in the GCC [8]. Figure 1 shows the investment per country from 2006 to 2015, while Figure 2 shows the fossil fuel savings from GCC's RE targets up to 2030.

This paper provides an up-to-date review of solar PV progress in the GCC member countries, discusses the challenges, and recommends strategies for future development of solar PV. Section 1 gives an introduction regarding the solar energy potentials and benefits in the GCC countries. In Section 2, the countries that constitute the GCC is described. Section 3 reviews the solar PV developments in the GCC countries such as Bahrain, Kuwait, the UAE, Qatar, Sultanate of Oman and the Kingdom of Saudi Arabia. Section 4 describes the RE sources in existing buildings and the barriers hindering full take up of RE in GCC countries. Finally, Section 5 presents the conclusions and suggestions for future improvements regarding RE sources integration in GCC countries. 


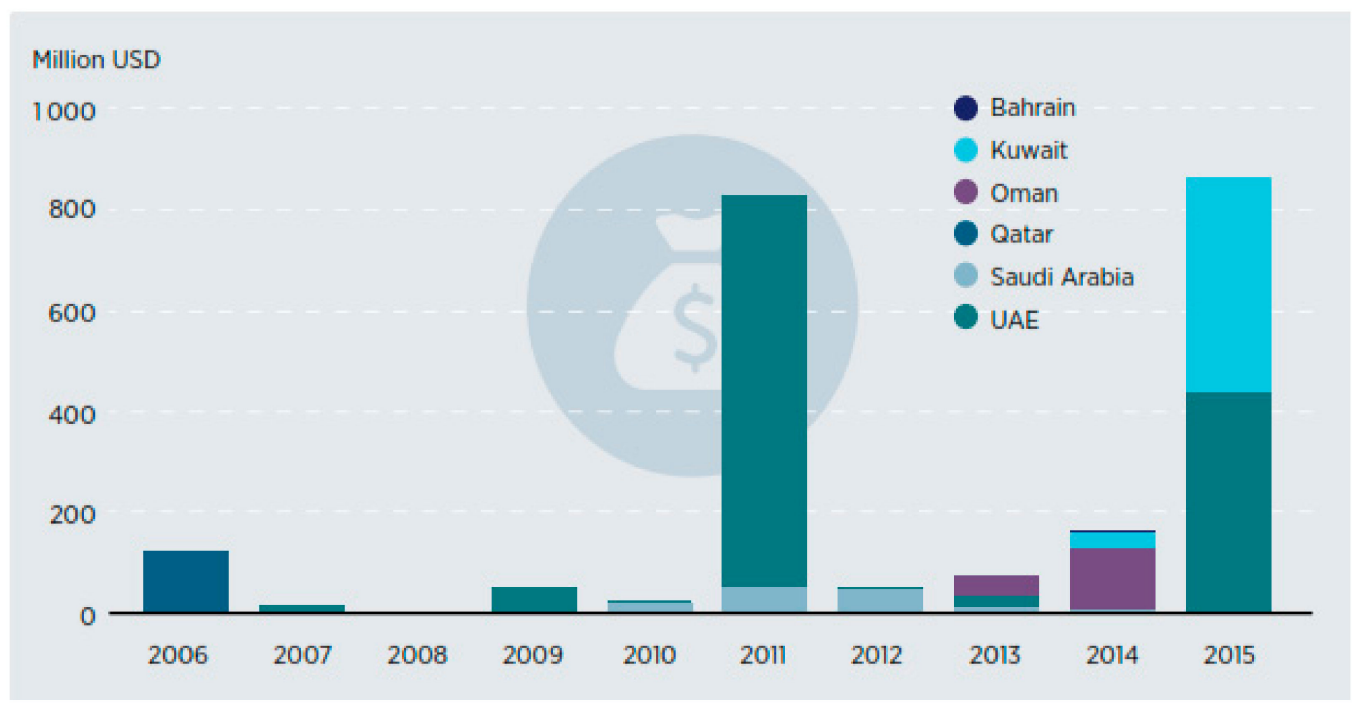

Figure 1. Investment in GCC Renewable Energy from 2006 to 2015 [8].

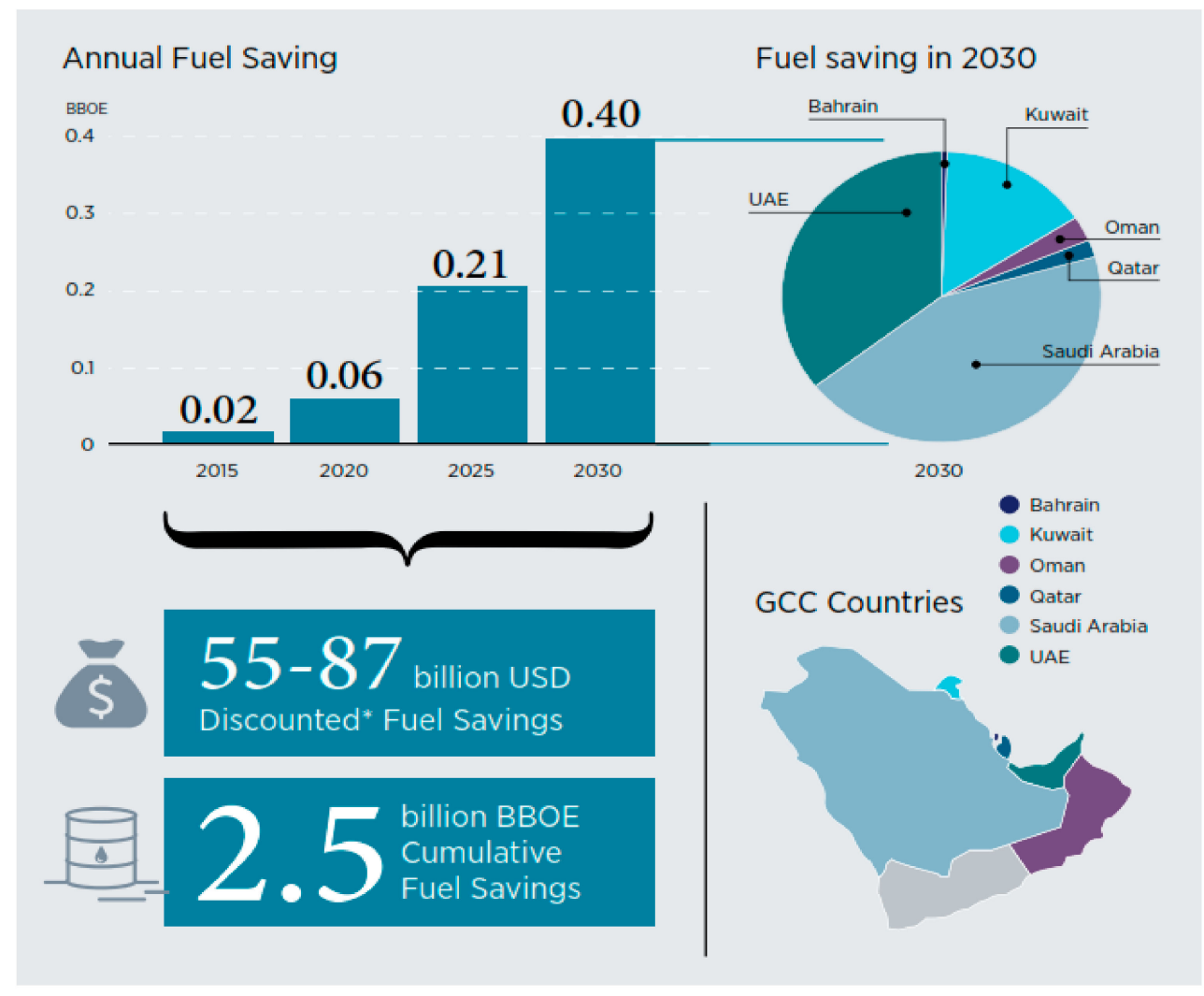

Figure 2. Fossil fuel savings from GCC RE targets by year and country [8].

\section{GCC Countries Background}

The GCC came into being by agreement on the 25 of May 1981 in Riyadh, Saudi Arabia between Bahrain, Kuwait, Oman, Qatar, the UAE and Saudi Arabia. The objectives of this union are to have greater coordination, integration and inter-connection between them in all fields of development [11]. GCC member states are also members of the Greater Arab Free Trade Area (GAFTA), with the exclusion of Yemen. Countries like Morocco and Jordan have applied for GCC member status, but this is still under study. The GCC member states' economy is one of the fastest growing due to oil and gas 
revenues. Some GCC countries such as Saudi Arabia, Kuwait and UAE are among the top ten of countries in the world, with long-term oil reserves as shown in Table 1.

Table 1. Top ten countries with largest oil reserves [12].

\begin{tabular}{ccc}
\hline Rank & Country & Barrels \\
\hline 1 & Venezuela & $300,000,000,000$ \\
2 & Saudi Arabia & $269,000,000,000$ \\
3 & Canada & $171,000,000,000$ \\
4 & Iran & $157,800,000,000$ \\
5 & Iraq & $143,000,000,000$ \\
6 & Kuwait & $104,000,000,000$ \\
7 & Russia & $80,000,000,000$ \\
8 & United Arab Emirates & $98,000,000,000$ \\
9 & Libya & $48,360,000,000$ \\
10 & Nigeria & $37,000,000,000$ \\
\hline
\end{tabular}

The organizational structure of GCC is made up of the Supreme Council, the Ministerial Council and the Secretariat General. The Secretarial General Office is located in Riyadh, Saudi Arabia. The main purpose of the GCC countries is to realize coordination, integration and cooperation in all fields of economic, social and cultural affairs [11]. The Supreme Council of the GCC is made up of the head of states of the six member's council and they meet once a year in an ordinary meeting. However, emergency meetings can be convened at any given time by the head of states of any two-member states. The Chairmanship of the Supreme Council is rotational among each member state. Resolutions are also passed by the majority. The foreign ministers from each member state form the Ministerial Council.

\section{Solar PV in GCC Countries}

\subsection{Bahrain}

The Kingdom of Bahrain has high-levels of solar radiation across the country. The mean yearly solar radiation in Bahrain is approximately $2180 \mathrm{kWh} / \mathrm{m}^{2}$ [5]. In 2009, Bahrain produced around 26.78 billion $\mathrm{kWh}$ of electricity and consumed about 26.09 billion $\mathrm{kWh}$ of electricity, which is regarded as the lowest level in the GCC countries [13]. The average daily sunshine hours in Bahrain are $9 \mathrm{~h}$.

Currently, the share of solar energy in the energy mix of the Kingdom of Bahrain is still insignificant as compared to the other GCC countries and it is the least producer of hydrocarbons in the GCC countries [14]. The primary energy source in Bahrain is natural gas $85 \%$ and the rest from oil [14]. There is no RE policy in Bahrain, and hence, no financial assurances to private investors to carry out RE projects in the Kingdom. However, Bahrain has one of the most liberal economies within the GCC, which allow foreign property ownership, the establishment of foreign companies without local partnership, low taxes and custom duties. There are no expiations of taxes on RE equipment or tax privileges for RE [15]. One well known RE project in Bahrain is the three parallel wind turbines at the Bahrain World Trade Centre. There is a proposal by the University of Bahrain for a mobile solar desalination unit $(1.5 \mathrm{~kW})$ capable of producing 250 gallons of water [16]. Already, $0.5 \mathrm{MW}$ solar electricity has been installed at the University of Bahrain (Figure 3a) [16]. The project has 2088 solar panels with a total area of $3400 \mathrm{~m}^{2}$. Each individual panel has a maximum of $240 \mathrm{~W}$ under standard test conditions. Currently, there is a pipeline of hybrid RE project involving $3 \mathrm{MW}$ (PV and concentrated solar power technology) and $2 \mathrm{MW}$ wind turbine developed by the Electricity and Water Authority of Bahrain [17].

The share of RE in Bahrain is planned to reach between 5\% and 7\% from electricity power generating capacity by 2030 [18]. The 2030 Energy Vision of Bahrain plans to achieve 7\% of total installed capacity from all RE sources by 2020. In 2012, a joint venture between Bahrain Petroleum Companies (BAPCO), National Oil and Gas Authority (NOGA) and two U.S based firms launched a 
5 MW solar PV project in Bapco, Bahrain [19]. The 5 MW Petra solar park in Manama has also been recently completed [19]. There are PV panels mounted for street lightning and carport in Alwali town (Figure $3 \mathrm{~b}, \mathrm{c}$ ). These comprises $1.51 \mathrm{MW}$ carports, $240 \mathrm{~kW}$ solar trees and $48 \mathrm{~kW}$ street light poles [20]. The BAPCO PV project was developed by US-based Petra Solar Inc., South Plainfield, NJ, USA [20]. Future projects include $5 \mathrm{MW}$ solar and wind project at Al Dur power and water plant [21,22].
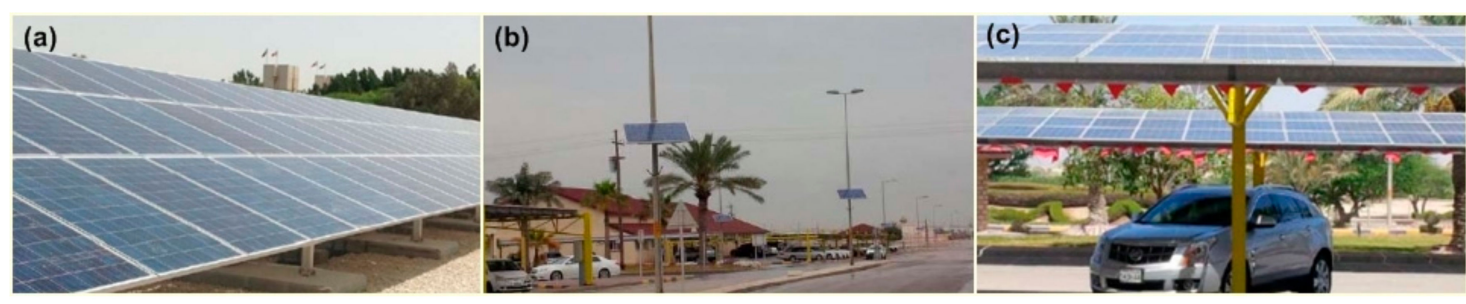

Figure 3. Selections of PV installations in Bahrain, where: (a) $0.5 \mathrm{MW}$ polycrystalline solar PV installed at the University of Bahrain; (b) PV panels mounted on street lights in Alwali town; and (c) PV panels mounted on carports in Alwali town. Adapted from [20].

\subsection{Kuwait}

Kuwait's annual solar radiation is predicted to be between 2100 and $2200 \mathrm{~kW} / \mathrm{m}^{2}$ [23]. The average daily sunshine hours/year for Kuwait range from 7 to 12 [24]. According to 2015 Kuwait Energy Policy, Laws and Regulations, the maximum solar radiation and the peak electricity demand in the country occurs at the same time of the year, making the solar PV the most useful RE source for the country [25]. The primary energy source of Kuwait is 100\% from fossil fuel with oil supplying $52.8 \%$ and natural gas $47.2 \%$ [26]. The energy consumption in Kuwait varies according to the following vectors: $33 \%$ industrial, $19 \%$ transport, $23 \%$ residential and 25\% non-energy uses and other consumption [27]. Kuwait energy resources are managed by the Kuwait Petroleum Corporation and its subsidiaries are responsible for oil and gas production, exporting, importing and distribution [25].

The acceptance of the Kyoto protocol by Kuwait in March 2005 allowed the country to rethink a plan for RE policy in agreement with the climate change mitigation objectives [25]. Since then, there are Research and Development (R\&D) initiatives by the government aimed at promoting the application of solar PV and solar thermal systems in both public and private institutions [19]. An environmental and social impact assessment carried out in 2012 to examine the solar PV in the North Africa and the Middle East showed that solar PV could be cost-competitive with oil-fired power generation at a crude oil price of USD 100/barrel using a certain cost figure for PV technology [27]. Kuwait plans to expand the share of RE in the country's energy mix by $1 \%$ in the year 2020 and up to $15 \%$ by 2030 [28]. The first stage involves developing solar (up to $60 \mathrm{MW}$ ) and wind (10 MW) by 2016 in Shagaya town [29]. Subsequent stages consist of developing up to $1000 \mathrm{MW}$ of solar and wind installations by the year 2020 and reaching up 2000 MW by 2030 [22]. The Kuwaiti government has already set aside up to USD 9.9 billion for developmental projects including RE [22].

Numerous solar projects have been implemented in Kuwait since the Gulf War of 1990. These include projects on solar cooling, solar PV for street lighting and traffic signals as shown in Figure 4 [30]. Recently the government of Kuwait signed a contract of 385 million USD with a Spanish firm (TSK Group) for the development of $50 \mathrm{MW}$ solar energy projects in the country [31]. The current and future RE projects in Kuwait are summarized in Tables 2 and 3, with information regarding component specifications. 


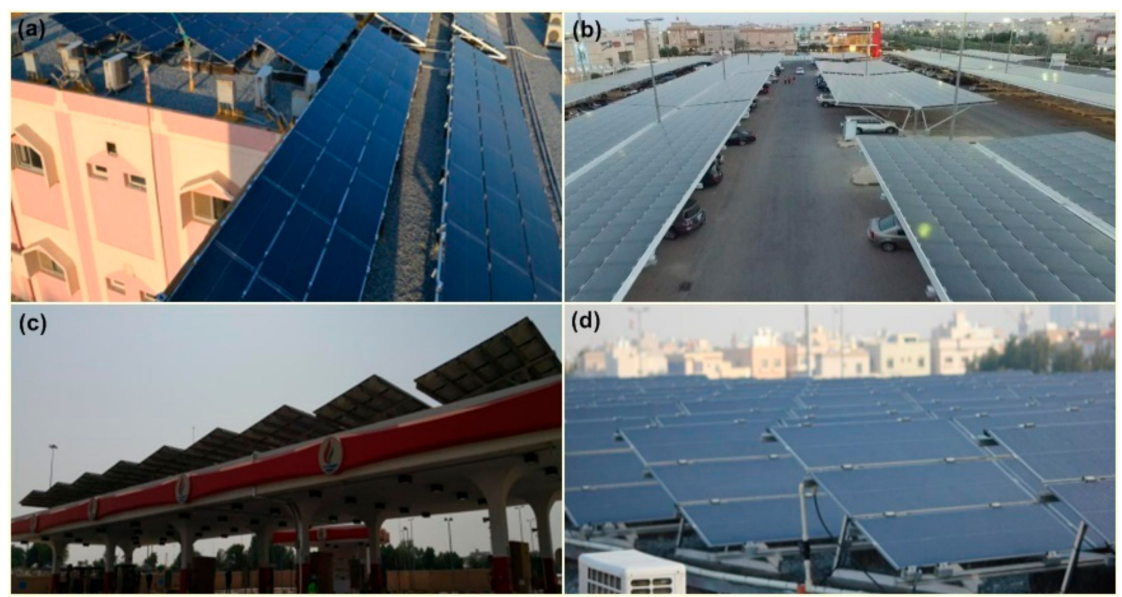

Figure 4. Solar projects in Kuwait: (a) Sawda bin Zamaa PV rooftop grid connected; (b) Al-Zahra Co-op Parking Shades PV Rooftop-Grid connected; (c) Al-Zahra Petrol Station PV Rooftop-Grid connected; (d) Azda bint alhareth School PV Rooftop-Grid connected. Adapted from [30].

Table 2. Current solar projects in Kuwait. Adapted from [30].

\begin{tabular}{cccccc}
\hline Solar Project & $\begin{array}{c}\text { Nominal } \\
\text { Power (kWp) }\end{array}$ & $\begin{array}{c}\text { No. of PV } \\
\text { Modules }\end{array}$ & $\begin{array}{c}\text { Number of } \\
\text { Batteries }\end{array}$ & $\begin{array}{c}\text { Battery Storage } \\
\text { Capacity (kWh) }\end{array}$ & $\begin{array}{c}\text { Voltage } \\
(\mathbf{V})\end{array}$ \\
\hline Kuwait English School (Salwa) & 24.2 & 630 & 110 & 220 & 220 \\
KISR's Solar House (Application Laboratory) & 2.6 & 76 & 48 & 34 & 48 \\
\hline
\end{tabular}

Table 3. Ongoing solar projects in Kuwait. Adapted from [30].

\begin{tabular}{ccccc}
\hline Solar Project & $\begin{array}{c}\text { Installed } \\
\text { Power (kWp) }\end{array}$ & PV Model & $\begin{array}{c}\text { No of PV } \\
\text { Modules }\end{array}$ & $\begin{array}{c}\text { Inverter Model } \\
\text { Energy per Year } \\
\text { (MWh/Year) }\end{array}$ \\
\hline $\begin{array}{c}\text { Azda bint alhareth } \\
\text { School PV Rooftop-Grid } \\
\text { connected }\end{array}$ & 50.4 & $\begin{array}{c}\text { CSG-Model } \\
\text { MS150GG-02 }\end{array}$ & 567 & $\begin{array}{c}\text { SMA-Sunny } \\
\text { Tripower17000 } \\
\text { TL }\end{array}$ \\
\hline $\begin{array}{c}\text { Sawda bint Zamaa } \\
\text { School PV Rooftop-Grid } \\
\text { connected }\end{array}$ & 21.60 & $\begin{array}{c}\text { CSG-Model } \\
\text { MS150GG-02 }\end{array}$ & 144 & $\begin{array}{c}\text { SMA-Sunny } \\
\text { Tripower10000 } \\
\text { TL }\end{array}$ \\
$\begin{array}{c}\text { Al-Raqa Petrol Station } \\
\text { PV Rooftop-Grid } \\
\text { connected }\end{array}$ & 50.4 & VBHN240SE10 & 210 & Micro-0.25-I-OUTD-230 \\
\hline $\begin{array}{c}\text { Al-Zahra Petrol Station } \\
\text { PV Rooftop-Grid } \\
\text { connected }\end{array}$ & 71.0 & VBHN240SE10 & 252 & $\begin{array}{c}\text { SMA-Sunny } \\
\text { Tripower2000 } \\
\text { TLEE }\end{array}$ \\
\hline $\begin{array}{c}\text { Al-Zahra Co-op Parking } \\
\text { Shades PV Rooftop-Grid } \\
\text { connected }\end{array}$ & 752 & SF145-S & 5184 & SMA-Sunny \\
Tripower
\end{tabular}

\subsection{United Arab Emirates (UAE)}

Like other GCC countries, the UAE has huge solar potentials with the mean annual solar radiation of $2285 \mathrm{kWh} / \mathrm{m}^{2}$ and average sunshine of $10 \mathrm{~h}$ per day [32,33]. However, high-humidity and dust particles in the atmosphere reduce the solar intensity [34]. The primary energy sources in the UAE are natural gas $(60.6 \%)$, crude oil $(38.2 \%)$, coal $(1.1 \%)$ and the remaining is from renewables [26]. About $5.7 \%$ of the world oil reserve is in the UAE [26] and this is predicted to be wholly consumed in the next 90 years if the production remains at the same level [35]. The UAE is also having the 7th largest natural gas reserve in the world (equivalent to $3.3 \%$ of the world reserve) [26]. In 2008, the UAE propelled Masdar Enterprise to concoct an economic development program for a sustainable society using advanced energy technologies which include solar thermal energy, wind power, carbon capture 
and storage and hydrogen, to respond to long-term energy mix bearing in mind the depletion of oil and gas [36].

Currently, there is no policy or regulation for promotion of RE-and specifically solar in the UAE-because of certain factors such as high-subsidies on electricity, individual control of electricity by each of the Emirates of the country and a high-income rate [37]. However the government of the UAE is planning to build up to $1500 \mathrm{MW}$ RE plants (wind and solar) with a target of $7 \%$ energy mix by the year $2020,25 \%$ by 2030 and $75 \%$ by 2050 [38]. Table 4 shows some of the solar projects in the UAE. Figure 5 shows several visible solar projects in the UAE.

Table 4. Current solar energy plants in the UAE. Adapted from [38].

\begin{tabular}{|c|c|c|c|c|}
\hline Project & Location & Installed Capacity & Type of Equipment & Status \\
\hline Shams 1 & $\begin{array}{c}\text { Western Abu } \\
\text { Dhabi }\end{array}$ & $100 \mathrm{MW}$ & $\begin{array}{c}768 \text { parabolic trough } \\
\text { collectors }\end{array}$ & operational \\
\hline $\begin{array}{l}\text { Masdar city solar } \\
\text { PV plant }\end{array}$ & Masdar city & $\begin{array}{l}10 \mathrm{MW} \text { PV array and } 1 \\
\text { MW roof-top complex }\end{array}$ & $\begin{array}{l}87,780 \text { modules } \\
\text { monocrystalline and } \\
\text { thin film modules }\end{array}$ & operational \\
\hline $\begin{array}{c}\text { Abu Dhabi solar } \\
\text { rooftop } \\
\text { programme }\end{array}$ & $\begin{array}{l}\text { Abu Dhabi } \\
\text { government } \\
\text { buidings }\end{array}$ & $2.3 \mathrm{MW}$ & - & operational \\
\hline $\begin{array}{l}\text { Murawah island } \\
\text { PV plant }\end{array}$ & $\begin{array}{l}\text { Murwah island } \\
\text { off the coast of } \\
\text { UAE }\end{array}$ & $\begin{array}{l}500 \mathrm{~kW} \text { peak with solar } \\
\text { energy penetration up } \\
\text { to } 80 \%\end{array}$ & - & operational \\
\hline $\begin{array}{l}\text { Um Al-zomul off } \\
\text { grid power plant }\end{array}$ & $\begin{array}{l}\text { Located at the } \\
\text { desert (Um Al } \\
\text { zomul) }\end{array}$ & $\begin{array}{c}100 \mathrm{~kW} \text { peak with } \\
100 \% \text { farm power } \\
\text { demand }\end{array}$ & - & operational \\
\hline
\end{tabular}

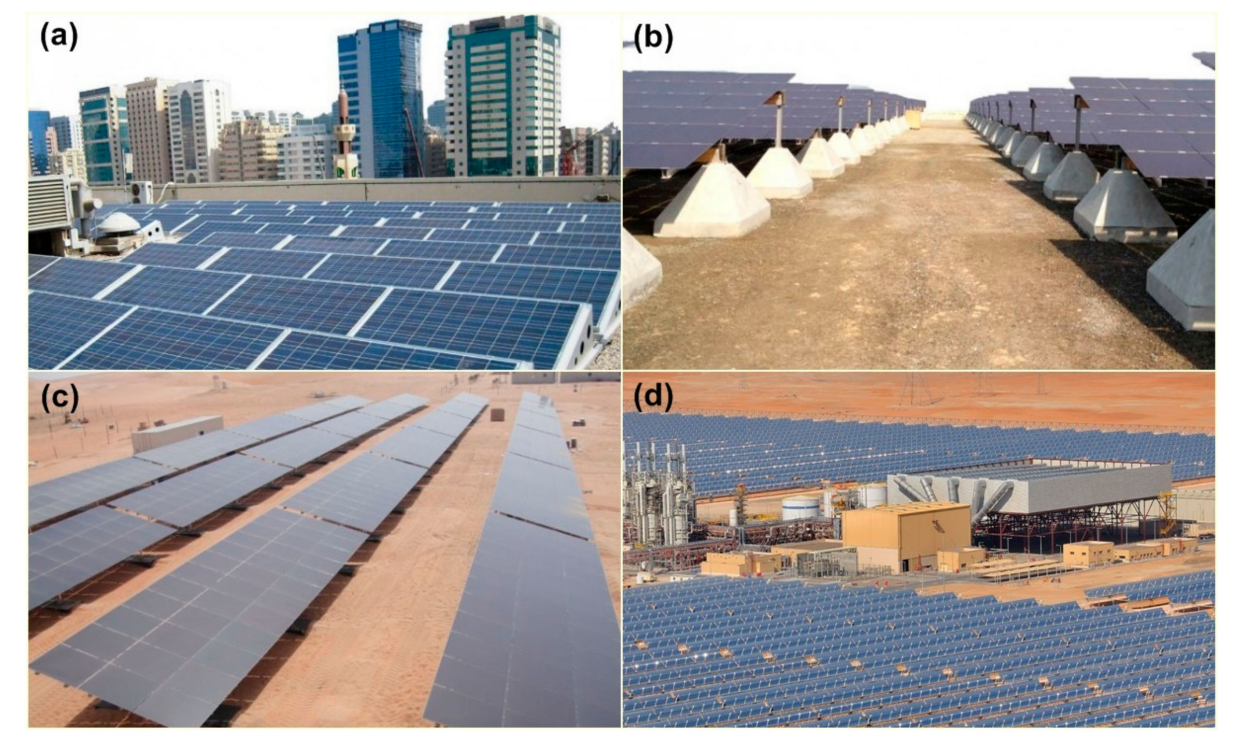

Figure 5. Solar projects in UAE: (a) Abu Dhabi solar rooftop; (b) Murawah Island PV Plant; (c) Um Al Zomul off-grid PV plant; and (d) Shams 1. Adapted from [38].

\subsection{Qatar}

Qatar is a country with abundant solar resources, reported to be up to $2113 \mathrm{kWh} / \mathrm{m}^{2} /$ year for the ground measured yearly average, calculated considering the 4-year period of coincident data [39]. Studies show that the presence of high-ambient temperature in Qatar coupled with dusty conditions affect the performance and reliability of PV panels [40]. A recent study shows that Qatar solar potentials 
are equivalent to 1.5 million barrels of crude oil annually [41]. The average sunshine hours in Qatar are 9.5 across the year. The primary energy sources in Qatar are natural gas (76\%) and crude oil (23\%) [26]. Qatar is regarded as the largest exporter of liquefied natural gas in the world [42]. Qatar has the world's 13 largest proven oil reserve and is the biggest gas producer.

There is no specific policy to facilitate the development of RE in Qatar like in many other states across the GCC. Qatar is investing in RE projects and investing in some RE technologies. Qatar planned a RE target of $20 \%$ by 2030 in which solar is incorporated [22]. Another source shows that Qatar is planning $16 \%$ of electricity from solar by the year 2018 [43]. Qatar government also planned a $20 \%$ decrease in per capita electricity consumption by the year 2018 [44]. The country also planned to establish a PV panel manufacturing plant in Ras Laffan city [22], which is vital for the development of solar PV in the country. To finance this plant, Qatar obtained USD 1 billion from Islamic lender Masraf Al Rayan [22]. At full capacity, this plant can produce up to $6.5 \mathrm{GW}$ [22]. As a plan to host the 2022 World Cup, Qatar is constructing five stadiums with major improvement to the public transport system using the solar technology [5]. Recently, Qatar utility company through a joint venture plans to create up to $1000 \mathrm{MW}$ solar power plant [42]. The Qatar utility companies will host $60 \%$ of the project while the remaining $40 \%$ will be hosted through a competitive tender process [42]. By 2030 Qatar targets generating 20\% of domestic energy need from renewable sources [22]. To this effect, Qatar General Electricity and Water Corporation stated that it first solar power will be operational by 2016 [45]. This solar power station will generate around $15 \mathrm{MW}$, at full capacity at Duhail and will increase to $200 \mathrm{MW}$ of solar power by 2020 and well fully operational will increase to $2 \%$ Qatar domestic energy requirement [45].

\subsection{Sultanate of Oman}

Oman is regarded as a country having the best solar resources in the world [46-48]. The annual solar radiation in Oman varies from 2200 to $2500 \mathrm{kWh} / \mathrm{m}^{2}$ [49]. The highest solar radiation in Oman is in Marmul, followed by Fahud, Sohar and Qairoon Hairiti [49]. According to the Oman RE report 2008 [47], Oman has the capability to supply enough electricity to meet its local needs through solar energy. However, humidity and dust plus a lack of rainwater are reported to be the barriers in using solar PV in Oman [50]. The Sultanate of Oman relies heavily on oil and gas for its economic development and natural gas has been used for power generation [51]. Oman has an excellent solar potential, but its application has been limited to street lighting, telephones in remote areas and traffic lights [52].

Most of the solar energy research in Oman is carried out by Sultan Qaboos University and Dhofar University and they are the leading institutions in disseminating of knowledge about solar and its importance to the Omanian society. A recent report [53] shows that Oman is carrying out a study to prepare RE policy. Areas of interest include evaluation of the RE resources of the country and setting the general framework and policy to kick start the RE development. However, there are several solar projects in the pipeline. These include a $300 \mathrm{~kW}$ solar project at Al Mazyonah-Dhofar, $1000 \mathrm{~kW}$ solar (PV-mono crystalline) project at Haima-Al Wusta, $28 \mathrm{~kW}$ PV and storage system at Al Mathfa-Dhofar and $100 \mathrm{~kW}$ PV solar project in Hiji.

\subsection{Kingdom of Saudi Arabia}

The Kingdom of Saudi Arabia (KSA) lies within the world's solar belt [54]. The Arabian Peninsula has a yearly average solar radiation of $2200 \mathrm{kWh} / \mathrm{m}^{2}$ [6,55]. Research and development activities show that solar energy has diverse practical applications in the KSA [56]. Some of the practical applications of solar energy are in solar furnaces, interior illumination of buildings and concentrating collectors [6]. In other words, it can be applied in situations such as PV, solar-thermal systems and passive solar design. The first PV beacon application in the Kingdom was done by a French company at a small airport in Madinah Al-Munnawara and R\&D work for the development of solar energy technologies at King Abdulaziz City for Science and Technology (KACAST) [56]. 
The Kingdom's national policy for science and technology serves as the basis for future RE development in the kingdom. This policy complies with the goals, objectives and directions for future development of the country. Recently, the awareness on RE opportunities has risen due to the fall in oil prices and the fact that oil reserves are limited. In view of this, the government has established the King Abdullah City for Atomic and Renewable Energy (KACARE) to act as a RE center and monitor the strict implementation of RE policies. Since 2007, the government has established the center of research excellence in RE at the King Fahd University of Petroleum and Minerals to carry out research related to solar energy [57]. KSA has already planned to include $41 \mathrm{GW}$ of solar power by the year 2032 as an alternative source of energy [58]. Recently, the Saudi Arabian Solar Society has been established to help beginners in the solar industry by organizing regular seminars and educational workshops related to solar energy business [59]. Visible projects already executed in the kingdom are shown in Figure 6 and selected specifications are shown in Table 5. All the projects are stand alone, i.e., they are not grid connected. Future ongoing solar projects in the kingdom include $100 \mathrm{MW}$ solar project in Makkah, 10 MW Al-Khafji Plant and 1.8 MW King Abdullah Petroleum Studies and Research Centre (II) Project in Riyadh [60].

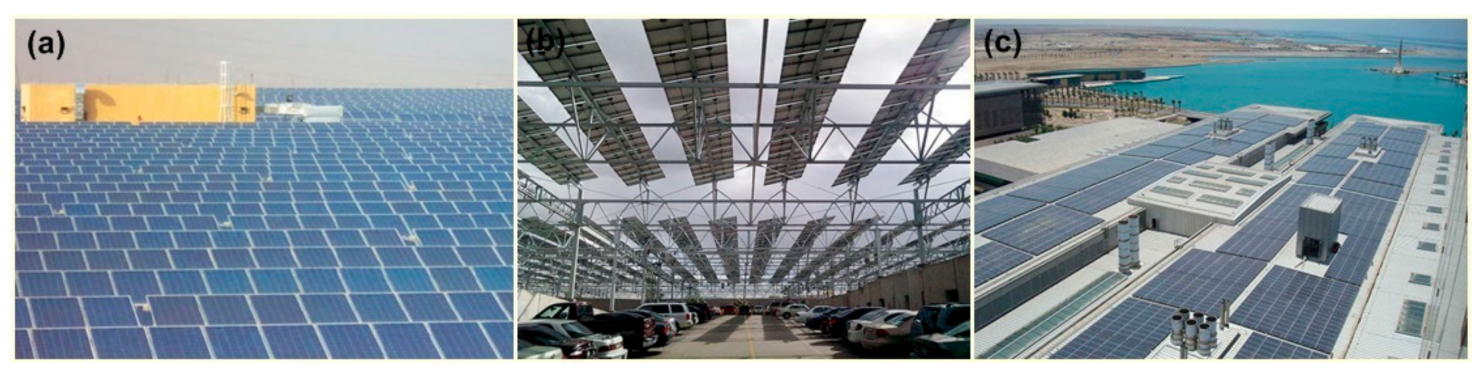

Figure 6. Solar PV projects in KSA: (a) King Abdullah Petroleum Studies and Research Center Solar Park; (b) Saudi Aramco solar car park, and (c) King Abdullah University of Science and Technology Solar Park. Adapted from [60].

Table 5. Selected solar projects in KSA. Adapted from [60].

\begin{tabular}{ccccc}
\hline Solar Project & Location & $\begin{array}{c}\text { Generating } \\
\text { Capacity (MW) }\end{array}$ & Purpose & Type of Equipment \\
\hline $\begin{array}{c}\text { King Abdullah Petroleum } \\
\text { Studies and Research } \\
\text { Center Solar Park }\end{array}$ & Riyadh & 3.5 & $\begin{array}{c}\text { To feed up to 2900 MWh } \\
\text { yearly into KAPSARC's } \\
\text { medium voltage grid. }\end{array}$ & $\begin{array}{c}\text { Polycrystalline silicon } \\
\text { substrate (Suntech STP } \\
\text { 280-24Vd) }\end{array}$ \\
\hline $\begin{array}{c}\text { Saudi Aramco Solar Car } \\
\text { Park }\end{array}$ & Dhahran & 10.5 & $\begin{array}{c}\text { To supply solar power to } \\
4500 \text { MW car park spaces. }\end{array}$ & $\begin{array}{c}\text { Thin film solar cells } \\
\text { (CIS type modules) }\end{array}$ \\
\hline $\begin{array}{c}\text { King Abdullah University } \\
\text { of Science and Technology } \\
\text { Solar Park }\end{array}$ & Thuwal & 2 & $\begin{array}{c}\text { To supply solar power to } \\
\text { certain university } \\
\text { buildings. }\end{array}$ & $\begin{array}{c}\text { Thin film solar } \\
\text { cells(SPR 215 W Solar } \\
\text { Panels) }\end{array}$ \\
\hline $\begin{array}{c}\text { King Abdulaziz } \\
\text { International Airport } \\
\text { Development Project }\end{array}$ & Jeddah & 5.4 & $\begin{array}{c}\text { To supply remote car } \\
\text { parking canopies. }\end{array}$ & $\begin{array}{c}\text { Thin film technology } \\
\text { (ARCO solar cells) }\end{array}$ \\
\hline
\end{tabular}

\section{Renewable Energy Integration in Buildings}

Buildings account for approximately $40 \%$ of the worldwide annual energy consumption in 2009 [61]. Benefits such as decreased building operational energy costs have prompted growing interest among policy makers, the technical community, the general public in addressing building energy issues and investigating solutions for decreasing building energy consumption. Therefore, there is a need for GCC to incorporate energy efficiency into new construction buildings and this is only possible through RE integration with building. Despite barriers in skilled manpower and lack of knowledgeable manpower in architectural concept, the building integration may result in 
cost reduction in terms of material and labour [62]. There is also an opportunity for reducing the building sector's contribution toward global energy consumption through reduction of energy use in existing buildings. Although the RE integration in buildings involves a wide-range of technological equipment with complex construction processes and high initial investment costs, its implementation in the long-term would lead to apparent economic benefits, thanks to energy savings, increased energy efficiency of buildings, environmental protection and safety.

Building integration with PV refers to designs with or without ventilated fluid (air or water), which is able to cool the PV panels and increase the electrical output, and the fluid is then exhausted to the ambient. Whereas for the building integration with PV-thermal, ventilated fluid is used as the working fluid to collect heat from the PV panel for heating or drying purposes. The building integration could be with PV, as well as in combination of PV thermal either air-based or water-based. It was also found that PV as well combine PV, thermal natural ventilated systems gave almost similar performances to the forced ventilated system [62]. Because of growth in PV technology as well as increasing interest in PV integration with building, companies are now more efficient in obtaining benefits of installing PV panels and PV-thermal panels in buildings. These building integrations with PV could be with walls, roof, PV-thermal-wall-air, PV-thermal-wall-water, PV-thermal-roof-air and PV-thermal-roof-water. Building integration with PV air-based could simply be delivered from single channel and double channels, as shown in Figure 7.

\section{Single Air Channel}

Ex.

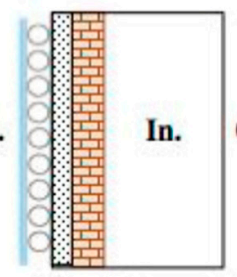

From left to right:

Glass pane, glass tube with air inside, insulation, façade / glass pane

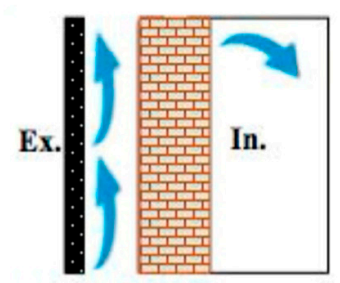

From left to right: PV panel, air cavity, insulation, facade

\section{Double Air Channels}

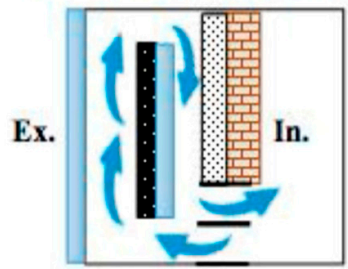

From left to right: glazing, outer air duct, PV panel, glaze, inner air duct, insulation

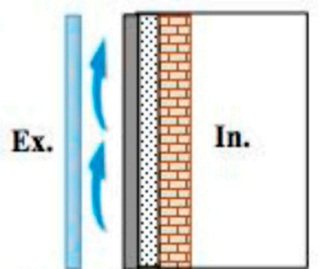

From left to right:

glazing, absorber, insulation, facade

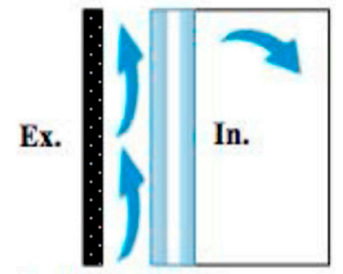

From left to right: PV panel, air cavity, double glazing

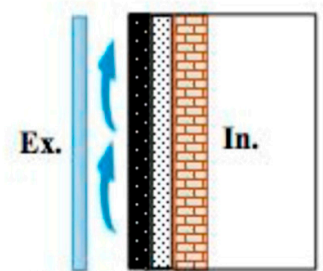

From left to right:

glazing, PV panel, insulation, facade

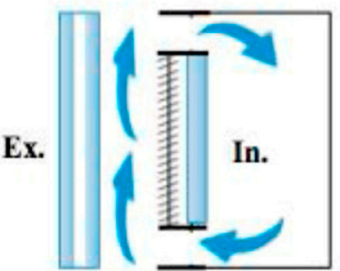

From left to right:

double glazing, air cavity,

Venetian blind, internal glazing

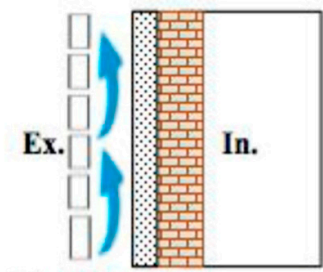

From left to right: transpired plate, air cavity, insulation, façade

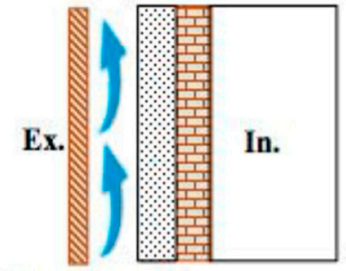

From left to right:

external sheet, air cavity, insulation facade

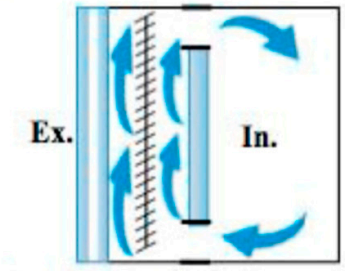

From left to right:

double glazing, $1^{\text {st }}$ air cavity, Venetian blind, $2^{\text {rd }}$ air cavity, internal glazing

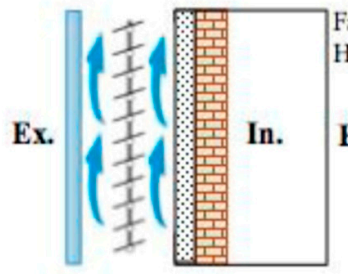

From left to right: glazing, cooled PV panel, insulation, facade

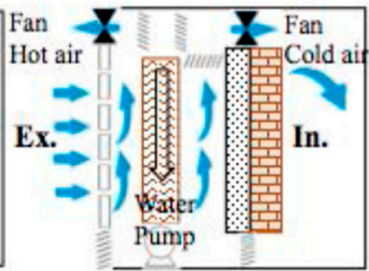

From left to right: transpired plate, Plenum 1, high porosity Sandtile, Plenum 2, insulation, facade

Figure 7. Schematics of different air-based building integration with PV [63]. 
The efficiency of PV cells drops with increasing temperature, therefore, a hybrid system known as a PV-thermal collector has been introduced to address this problem. Integrating PV thermal collectors onto or into buildings can improve the energy profile of buildings by reducing electrical and thermal loads of heat pumps and simultaneously providing hot air or hot water for the occupants or for drying and washing purposes. The PV-thermal integration into buildings requires additional installation costs such as frames and a pump for fluid circulation. Thus, a higher installation cost is required, which makes the building integrated PV-thermal systems relatively less attractive.

Barriers of PV integration with building and PV-thermal integration with building applications include technological limitations, financial issues such as high-initial costs, lack of financial assistance or subsidies, and social aspects such as low acceptance level and public awareness. These are the common limitations of green technologies and need to be addressed in order to create the market for business, reduce the PV panel prices and thus increase the number of installations [62]. Figure 8 demonstrates different water-based Building integration with PV-thermal.

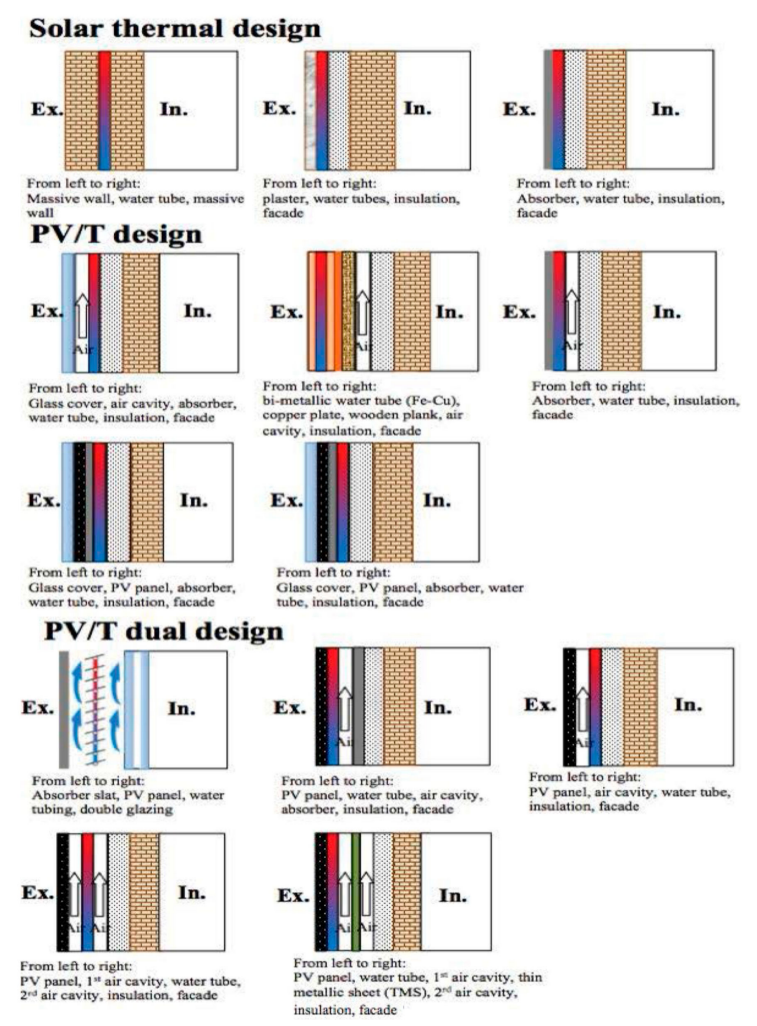

Figure 8. Schematics of different water-based Building integration with PV-thermal [63].

Another area the GCC countries could look at is the use of solar chimneys, due to their utilization in reducing heat gain and inducing natural cooling or heating in both commercial and residential buildings, because of their potential benefits in terms of operational cost, energy requirement and carbon dioxide emission [64]. In civil buildings, solar chimneys can be installed on the walls and roofs. For the purpose of improving natural ventilation performance and achieving better indoor thermal comfort, solar chimneys are always applied in the form of integrated configurations; at roof either, with solar collector or walls of the building with also solar collector. It was reported in [64] that a residential building with integrated solar chimney consume $10 \%$ to $20 \%$ less electrical power than conventional systems. Solar chimney can be combined with evaporative cooling, underground and solar cooking as a natural cooling to achieve the desired results.

There was also an attempt to analyze solar chimney integrated with earth to air heat exchanger, to investigate the cooling and ventilation in a solar house through the combined solar chimney and 
underground air channel [65]. The finding shows that the solar chimney can be perfectly used to power the underground cooling system during the daytime, without any need to electricity.

\subsection{Renewable Energy in Existing Buildings}

Another issue that the GCC nations can consider in their visions is how to reduce the energy consumption of existing buildings. This can be achieved by either reducing the need for energy through the implementation of energy efficiency measures or offsetting the remaining energy needs of the buildings using RE systems [61] (Figure 9). National and local policies are being implemented in both developed and developing countries that require greater amounts of energy to come from RE resources.

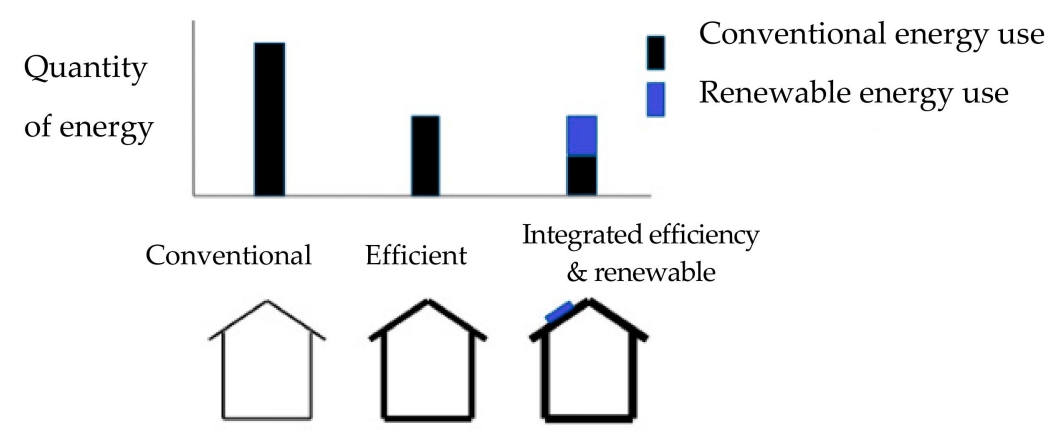

Figure 9. Demonstration of how combining energy efficiency and RE strategies significantly reduces total building conventional energy use [61]. National Renewable Energy Laboratory.

As policies such as these are enacted, incentives for installing RE systems are also being developed and regulatory barriers are being removed. The use of RE systems for meeting building energy needs is also becoming a mean for demonstrating leadership in environmental sustainability and resource conservation, increasing the reliability of on-site electrical and thermal energy supplies, addressing energy security issues, and other benefits.

These actions are encouraging those who are making decisions regarding existing building retrofit projects to seek out ways to use RE systems to meet sustainable building goals. In addition, these actions encourage those who are paying for the energy use associated with these buildings to explore using RE systems as a means to reduce utility costs, and in many cases, the building's carbon footprint.

\subsection{Barriers Hindering Full Take up of RE in GCC Countries}

\subsubsection{Technical Challenges}

There are several technical challenges facing RE development in the GCC countries. These include stand-by capacity, land use issues and storage [66]. Besides, there is intermittency in solar radiation coupled with problems of sand and dust accumulation on solar panels. The situation can worsen during the winter season when there is serious fog combining with dust particles thereby reducing the efficiency of the solar panels. Subsequently, there is a lack of rainfall in the region, which can help in cleaning the panels naturally. Gastli and Charabi [67] reported that $4 \mathrm{gm} / \mathrm{m}^{2}$ of dust can reduce solar panel efficiency by $40 \%$. Khatib et al. [68] investigated the effect of dust deposition on the performance of multi-crystalline PV modules based on some experimental measurements, and concluded that the decrease in PV power and voltage is strongly dependent on the contaminant type and the level of deposition. Solar panels contaminant considered for the study includes sand, ash, calcium carbonate, and silica. The results further show that ash contaminants appear to have the strongest effect on the solar panels as compared to the others with PV voltage reduction of almost $25 \%$. Baras et al. [69] investigated the effect of temperature on the performance of solar panels in 
Saudi Arabia, and concluded that high-ambient temperature coupled with exposure to long sunshine increases the impact of temperature on PV panels. Table 6 shows the power reduction due to the increase in temperature for different PV cells.

Table 6. The rate of power reduction in PV panels due to temperature [69].

\begin{tabular}{cc}
\hline PV Type & Power Reduction $\left(\% /{ }^{\circ} \mathbf{C}\right)$ \\
\hline Thin-film Silicon & 0.48 \\
Crystalline silicon (c-Si) & 0.45 \\
Amorphous silicon (a-Si) & 0.13 \\
Copper indium (CIGS) & 0.36 \\
\hline
\end{tabular}

Technical collaboration between GCC institutes for solar development and international partners is a challenge, which needs to be addressed by all GCC countries as a region. There is also a lack of local content in solar energy technology, which is a challenge for all GCC countries. Another key challenge is that there is no solar panel manufacturing plants in the GCC member countries.

\subsubsection{Inadequate Public/Private Initiatives}

There appear to be no official private and public initiative programs for solar energy development. The coming together of private and government initiatives can drive direct foreign investment into the RE in the region. There is also no collaborative approach among the GCC or governmental organizations for RE development. This is important for fair distribution of resources or benefits obtained from these RE sources. There is also no forum for exchange of scientific advice among GCC meetings through seminars or regular workshops.

\subsubsection{Dependence on Oil and Gas}

For the solar energy industry to develop within the GCC countries there is a need to reduce local dependence on oil and gas. These issues, among other things, have left the industry with no guidelines or productive partnership with potential foreign investors.

\subsubsection{Inadequate Research and Development Capabilities}

The solar energy industry requires qualified personnel, engineers, technicians and designers. It is a fact that for solar energy industry to develop there is a need for research and development regarding the technology, material and application. However, there are several solar research institutes in the GCC, but research outputs are slow. Presently, there is no data bank for solar radiation, temperatures, wind speed, and dust particles for effective research within the GCC.

\subsubsection{Inadequate Legislation and Regulatory Framework}

There is a lack of national policy strategies among the GCC countries to promote RE. Most of the activities in RE within the region are linked to $R \& D$ and are not well thought out as an internal part of national energy plans. There are some successes in the promotion of RE, however; there are still some limitations due to national policy framework strategies. These strategies can even encourage local, as well as international investment in RE within GCC countries.

\subsubsection{Insufficient Application of Building Integration Technology RE}

For efficient energy saving, there is the need to look at the possibility of integrating the RE with building. According to Hayter et al. [61], it is vital to take consideration of technical issues, i.e., efficiency, effectiveness, safety, durability and flexibility, together with constructive and formal issues at the early design stage of building integrated to RE. One solution is the installation of the PV array on building where the building plays a supporting role to PV. The integration of PV array with 
building is that the PV modules appear as the building material and the PV array becomes the integral part of the construction, such as photoelectric tile roofs, photoelectric curtain walls and photoelectric lighting roofs [62]. Most of the GCC countries still rely on the traditional ways of installing PV on rooftops. This lack of building-integrated RE in the GCC, as well as the corresponding structural and construction detail handling, the initial investment of RE and building integration technology is high and the construction cost is also high [64]. However, with the use of RE, the economic benefits generated from its energy conservation, environmental protection, safe and efficient will become increasingly apparent.

\section{Conclusions and Recommendations for Future Improvements}

There has been a great development of RE, especially solar, within the GCC countries. However, these developments have been done as current projects or future projects without necessary underpinning it with strategic policy development plans, which could have driven other players into the projects. Figure 10 shows the percentage of total RE sources installed within the GCC countries.

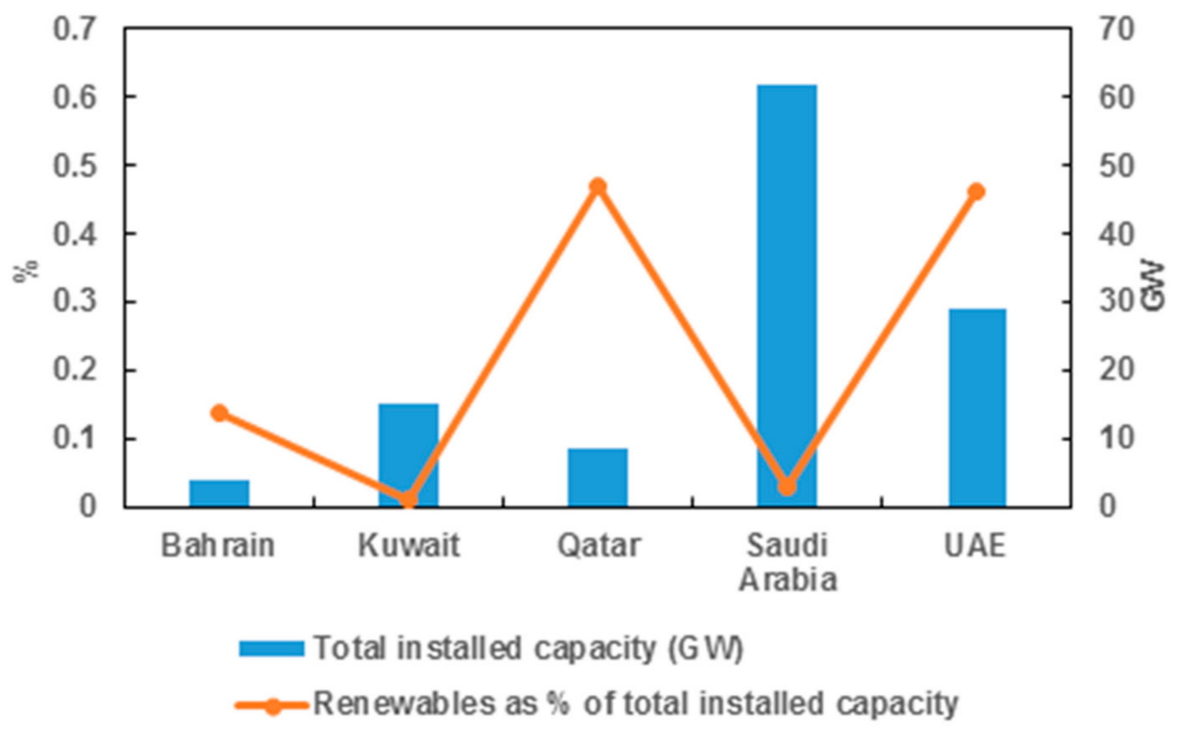

Figure 10. Percentage of RE sources in terms of total installed capacity [70].

In addition, there are high ambitions for deploying future solar energy installations as shown in Figure 11. Table 7 summarizes the solar PV development in the GCC countries. The potentials are enormous for all the GCC countries concerning solar PV, but could be enhanced by installing solar PV on rooftop of many new buildings within GCC countries. It is also important to assess the integration of solar PV to the grid using smart techniques. There is need for the formation of micro grids to facilitate full integration. This paper highlighted some of the challenges hindering the development of RE in the GCC which include the effect of weather conditions on the performance of PV panels, Inadequate research and development capabilities, Inadequate legislation and regulatory framework and the application of building integration technology RE which is yet to take to fully take up. Therefore, there is a need for these countries within GCC to vigorously address these challenges as a way forward. Other areas necessary to promote the use of solar energy in the GCC countries include:

(1). Exchange of knowledge and scientific advice amongst the universities and research centers of the GCC countries. The GCC governments can establish R\&D policies in conjunction with academic and industrial stakeholders to achieve this mutual cooperation. In essence, stronger linkages between government, academia and industries are necessary to facilitate greater funding in RE from the private sector. There is a need for further research, into the optimum solar technology, 
for application in the GCC countries. Currently applied technologies include mono-crystalline, polycrystalline and thin film. It is important to access their performance in indirect light, high heat and their adaptability to the GCC environment. It is evident that due to high summer temperatures within the GCC countries, PV modules may lose efficiency with time, but basically this depends on the type of PV module. To address this situation, Griffiths and Mills [71] propose that incentives and standards must be aligned with the country's climatic situation to maximize the power output.

(2). Involve international collaboration to develop the solar energy market and evaluate all project accomplishments. Already, UAE through the Masdar initiative has established international collaborations and this has led to several international projects such as Baynouna Solar Energy Project in Jordan, Siwa Solar PV Plant in Egypt, Solar home systems in Afghanistan [38], but other GCC countries could learn and develop collaborative international projects.

(3). Create awareness in colleges and universities for enhanced research in solar energy. There is a need to update curricula to include RE courses in engineering based programs.

(4). Establishing feed-in-tariffs (FiTs) for solar energy. FiTs are common policy type in the power industry globally. Already the Saudi Arabian government are considering FiTs for small-scale projects while the UAE are planning to introduce green tariffs [9]. FiT programs are essential to ensure that customers who own appropriate rooftop solar PV installations get a financial reward from utility for the power they generate and supply to the grid over a certain period. One excellent FiT technique that can be adopted by the GCC countries is from Jacobs and Sovacool [72]. The fundamental technique from this work is adopting international standards in the design of local RE instruments aimed at stabilizing the income from RE projects thereby minimizing the RE electricity as much as possible.

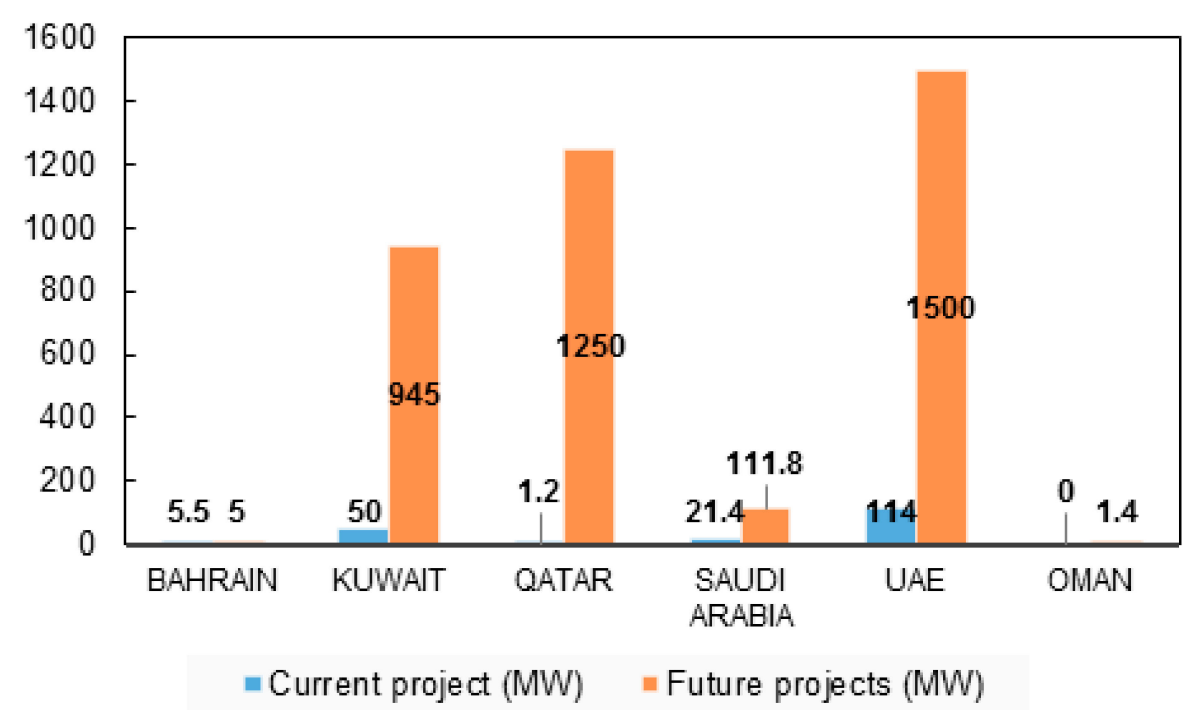

Figure 11. Current and future planned solar projects in the pipeline in the GCC countries. 
Table 7. Summary of solar PV development in the GCC countries.

\begin{tabular}{|c|c|c|c|c|c|}
\hline Country & $\begin{array}{l}\text { Solar Energy Target Share in } \\
\text { Total Installed Capacity }\end{array}$ & $\begin{array}{l}\text { Primary Energy } \\
\text { Sources }\end{array}$ & $\begin{array}{l}\text { Maximum Solar } \\
\text { Insolation } \\
\left(\mathbf{k W h} / \mathrm{m}^{2} / \text { Year }\right)\end{array}$ & $\begin{array}{l}\text { Current Operational Solar } \\
\text { Projects }\end{array}$ & Future Projects \\
\hline Bahrain & $\begin{array}{l}5 \% \text { of all renewable including } \\
\text { solar }(2020) \text {. }\end{array}$ & Oil, gas & 2180 & $\begin{array}{l}0.5 \mathrm{MW} \text { solar plant at the bahrain } \\
\text { university } \\
5 \mathrm{MWp} \text { Bapco pilot plant at Bapco. }\end{array}$ & $5 \mathrm{MW}$ solar project at $\mathrm{Al}$ Dur power and water plant. \\
\hline Kuwait & $\begin{array}{c}1 \% \text { in } 2015,10 \% \text { by } 2020 \text { and } \\
15 \% \text { by } 2030 \text {. }\end{array}$ & Oil, gas & 2200 & See Table 1 & $50 \mathrm{MW}$ solar project across the country. \\
\hline UAE & $\begin{array}{l}7 \% \text { of all renewables by } 2020 \\
25 \% 2030 \text { and } 75 \% \text { by } 2050 \text {. }\end{array}$ & Oil, gas & 2285 & See Table 2 & 1000 MW Mohammed bin Rashid Al Maktoum Solar Park. \\
\hline Qatar & $\begin{array}{l}20 \% \text { of all renewables with } \\
\text { solar incorporated by } 2030 \\
\text { and } 15 \% \text { solar by } 2018 .\end{array}$ & Oil, gas & 2113 & $\begin{array}{l}\text { Establishment of solar PV } \\
\text { manufacturing plant in Ras Lafin. }\end{array}$ & $\begin{array}{l}\text { Stadiums with solar technology cooling for the football World } \\
\text { Cup 2022; } 1000 \text { MW solar PV plant in Doha. }\end{array}$ \\
\hline Oman & $10 \%$ by 2020 . & Oil, gas & 2500 & See Section 3.5 & $\begin{array}{l}300 \mathrm{~kW} \text { solar project at Al Mazyonah-Dhofar; } 1000 \mathrm{~kW} \text { solar } \\
\text { project in Haima, } 28 \mathrm{~kW} \text { PV and storage system at Al } \\
\text { Mathfa-Dhofar; } 100 \mathrm{~kW} \text { PV in Hijji. }\end{array}$ \\
\hline $\begin{array}{l}\text { Kingdom of Saudi } \\
\text { Arabia }\end{array}$ & $\begin{array}{l}54 \mathrm{GW} \text { from renewables } \\
\text { including solar technology. }\end{array}$ & Oil, gas & 2200 & See Table 3 & $\begin{array}{l}\text { 1000 MW solar plant in Makkah; } 10 \text { MW Al-Khafji plant; } \\
\text { 1.8 MW King Abdullah Petroleum studies and Research centre. }\end{array}$ \\
\hline
\end{tabular}


Acknowledgments: The authors would like to thank all institutions in which they are providing service: Jubail Industrial College, University of Sheffield, Robert Gordon University and Universidad Politécnica de Madrid. Besides, they would like to thank to MDPI for promoting open-access to knowledge, evenmore, providing discounts to reviewers that helps in publishing open-access research like this work.

Author Contributions: All authors contributed in writing, proofreading and providing suggestions for improving the paper.

Conflicts of Interest: The authors declare no conflict of interest.

\section{References}

1. Carmalt, S.W.; St. John, B. Giant oil and gas fields. In Future Petroleum Provinces of the World; Halbouty, M.T., Ed.; American Association of Petroleum Geologists Memoir: Tulsa, OK, USA, 1986; pp. 11-54, ISBN 978-1-62981-144-4.

2. Ismail, A.M.; Ramirez-Iniguez, R.; Asif, M.; Munir, A.B.; Muhammad-Sukki, F. Progress of solar photovoltaic in ASEAN countries: A review. Renew. Sustain. Energy Rev. 2015, 48, 399-412. [CrossRef]

3. Fowler, S.W. Pollution in the Gulf: Monitoring the marine environment. IAEA Bull. 1993, 35, 9-13.

4. Ferroukhi, R.; Ghazal-Aswad, N.; Androulaki, S.; Hawila, D.; Mezher, T. Renewable energy in the GCC: Status and challenges. Int. J. Energy Sect. Manag. 2013, 7, 84-112. [CrossRef]

5. Alnaser, W.E.; Alnaser, N.W. The status of renewable energy in the GCC countries. Renew. Sustain. Energy Rev. 2011, 15, 3074-3098. [CrossRef]

6. Hepbasli, A.; Alsuhaibani, Z. A key review on present status and future directions of solar energy studies and applications in Saudi Arabia. Renew. Sustain. Energy Rev. 2011, 15, 5021-5050. [CrossRef]

7. Sunwater Solar. What Is Solar Thermal? Available online: http://sunwatersolar.com/solar-thermal/whatis-solar-thermal (accessed on 16 November 2017).

8. International Renewable Energy Agency (IRENA). Renewable Energy Market Analysis: The GCC Region; IRENA: Abu Dhabi, UAE, 2016.

9. Ferroukhi, R.; Doukas, H.; Androulaki, S.; Menichetti, E.; Masini, A.; Khalid, A. EU-GCC Renewable Energy Policy Cooperation: Exploring Opportunities. In EU-GCC Renewable Energy Policy Experts' Workshop; Gulf Research Center: Abu Dhabi, UAE, 2013; pp. 1-44.

10. Holland+You. Opportunities for Dutch Business in the Gulf Region; Holland+You: The Hague, The Netherlands, 2016.

11. Gulf Cooperation Council (GCC). Available online: http://www.mea.gov.in/Portal/ForeignRelation/Gulf_ Cooperation_Council_MEA_Website.pdf (accessed on 6 November 2017).

12. CIA. Country Comparison: Crude Oil Proved Reserves. Available online: https://www.cia.gov/library / publications/the-world-factbook/rankorder/2244rank.html (accessed on 16 November 2017).

13. Central Intelligence Agency (CIA). Bahrain. Available online: https:/ /www.cia.gov/library/publications / the-world-factbook/geos/ba.html (accessed on 17 December 2017).

14. Bachellerie, J.I. Renewable Energy in the GCC Countries: Resources, Potential and Prospects, 1st ed.; Gulf Research Center: Jeddah, Saudi Arabia, 2012; ISBN 9789948490050.

15. Regional Center for Renewable Energy and Energy Efficiency (RCREEE). Renewable Energy Country Profile: Bahrain; RCREEE: Cairo, Egypt, 2013.

16. Abdmouleh, Z.; Alammari, R.A.M.; Gastli, A. Recommendations on renewable energy policies for the GCC countries. Renew. Sustain. Energy Rev. 2015, 50, 1181-1191. [CrossRef]

17. Munawwar, S.; Ghedira, H. A review of renewable energy and solar industry growth in the GCC region. Energy Procedia 2014, 57, 3191-3202. [CrossRef]

18. Al-Shalabi, A.; Cotteret, N.; Menichetti, E. EU-GCC Cooperation in Energy. In Bridging the Gulf: EU-GCC Relations at a Crossroads; Colombo, S., Ed.; Edizioni Nuova Cultura: Roma, Italy, 2014; p. 357, ISBN 8868122847.

19. Ramadhan, M.; Naseeb, A. The cost benefit analysis of implementing photovoltaic solar system in the state of Kuwait. Renew. Energy 2011, 36, 1272-1276. [CrossRef]

20. Alnaser, W.E.; Alnaser, N.W.; Batarseh, I. Bahrain's BAPCO 5MWp PV Grid-Connected Solar Project. Int. J. Power Renew. Energy Syst. 2014, 1, 72-84.

21. Oxford Business Group. Bahrain Brings New Utility Projects to Light. Available online: http://www. oxfordbusinessgroup.com/news/bahrain-brings-new-utility-projects-light (accessed on 17 November2017). 
22. Meltzer, J.; Hultman, N.; Langley, C. Low Carbon Energy Transitions in Qatar and the Gulf Cooperation Council Region; Brookings: Washington, DC, USA, 2014.

23. Alsharhan, A.S.; Rizk, Z.A.; Nairn, A.E.M.; Bakhit, D.W.; Alhajari, S.A. Hydrogeology of an Arid Region: The Arabian Gulf and Adjoining Areas, 1st ed.; Elsevier Science: Amsterdam, The Netherlands, 2001; ISBN 9780080534329.

24. Al-Hasan, A.Y. Electricity generation cost between proposed photovoltaic station and conventional units in Kuwait. Renew. Energy 1997, 12, 291-301. [CrossRef]

25. International Business Publications (IBP). Kuwait Energy Policy, Laws and Regulations Handbook: Strategic Information and Basic Regulations, 1st ed.; International Business Publications USA: Washington, DC, USA, 2015; ISBN 9781438727738.

26. BP. BP Statistical Review of World Energy 2017; BP: London, UK, 2017.

27. Alsayegh, O.A.; Fairouz, F.A. Renewable energy supply options in Kuwait. World Acad. Sci. Eng. Technol. 2011, 60, 870-875.

28. International Energy Agency (IEA). Kuwait Renewable Energy Target. Available online: https://www.iea. org/policiesandmeasures/pams/kuwait/name-157557-en.php (accessed on 21 November 2017).

29. Oxford Business Group. New Solar Projects Come On-Line in Kuwait. Available online: https:/ / www.oxfordbusinessgroup.com/analysis / catch-sun-solar-power-making-significant-progresscutting-costs-and-reducing-emissions (accessed on 21 November 2017).

30. Aljandal, S. Overview of Grid Connected Rooftop Solar PV Projects in Kuwait. In Accelerating Residential Solar in the U.A.E: Innovative Solutions, Cost and New Opportunities; Dubai Electricity and Water Authority (DEWA): Dubai, UAE, 2015; pp. 1-24.

31. REVE. Kuwait Signs \$385 mn Solar Energy Project. Available online: https:/ /www.evwind.es/2015/09/10/ kuwait-signs-385-mn-solar-energy-project/54031 (accessed on 21 November 2017).

32. Mokri, A.; Ali, M.A.; Emziane, M. Solar energy in the United Arab Emirates: A review. Renew. Sustain. Energy Rev. 2013, 28, 340-375. [CrossRef]

33. Assi, A.; Jama, M.; Al-Shamisi, M. Prediction of Global Solar Radiation in Abu Dhabi. ISRN Renew. Energy 2012, 2012, 1-10. [CrossRef]

34. Zell, E.; Gasim, S.; Wilcox, S.; Katamoura, S.; Stoffel, T.; Shibli, H.; Engel-Cox, J.; Subie, M. Al Assessment of solar radiation resources in Saudi Arabia. Sol. Energy 2015, 119, 422-438. [CrossRef]

35. Ali, A.S. United Arab Emirates Food E Drink Report 2016; British Centres for Business: Dubai, UAE, 2017.

36. Al-Amir, J.; Abu-Hijleh, B. Strategies and policies from promoting the use of renewable energy resource in the UAE. Renew. Sustain. Energy Rev. 2013, 26, 660-667. [CrossRef]

37. Mezher, T.; Dawelbait, G.; Abbas, Z. Renewable energy policy options for Abu Dhabi: Drivers and barriers. Energy Policy 2012, 42, 315-328. [CrossRef]

38. Masdar. UAE Projects. Available online: http://www.masdar.ae/en/energy/uae-projects (accessed on 21 November 2017).

39. Bachour, D.; Perez-Astudillo, D. Ground-measurement GHI map for Qatar. Energy Procedia 2013, 49, 2297-2302. [CrossRef]

40. Martinez-Plaza, D.; Abdallah, A.; Figgis, B.W.; Mirza, T. Performance Improvement Techniques for Photovoltaic Systems in Qatar: Results of First year of Outdoor Exposure. Energy Procedia 2015, 77, 386-396. [CrossRef]

41. Energy Research Centre of the Netherlands (ECN). Private sector engagement-Qatar case study. In NDE Workshop Yerevan; ECN: Petten, The Netherlands, 2015; pp. 1-14.

42. Finn, T. Qatar Plans 1000 MW of Solar Power via Joint Venture, Utility Says. Available online: https: / / af.reuters.com/article/africaTech/idAFL8N1600T3 (accessed on 22 November 2017).

43. Qatar Electricity \& Water (QEWC). QEWC Seeks to Tap Solar Energy for Electricity. Available online: https:/ / www.qewc.com/qewc/en/index.php/qewc/77-gulf-times/110-qewc-seeks-to-tap-solar-energyfor-electricity (accessed on 22 November 2017).

44. Ansari, M. Kuwait Utilities Sector. Ind. Res. 2013, 1-15.

45. Marhaba. Qatar's Solar Energy Ambitions-Marhaba 1 Qatar's Premier Information Guide. Available online: https: / / www.marhaba.qa / qatars-solar-energy-ambitions/ (accessed on 22 November 2017).

46. International Renewable Energy Agency (IRENA). Sultanate of Oman: Renewables Readiness Assessment; IRENA: Abu Dhabi, UAE, 2013. 
47. COWI and Partners LLC. Study on Renewable Energy Resources, Oman; Authority for Electricity Regulation: Muscat, Sultanate of Oman, 2008.

48. Al-Badi, A.H.; Malik, A.; Gastli, A. Assessment of renewable energy resources potential in Oman and identification of barrier to their significant utilization. Renew. Sustain. Energy Rev. 2009, 13, 2734-2739. [CrossRef]

49. Al-Badi, A.H.; Malik, A.; Gastli, A. Sustainable energy usage in Oman-Opportunities and barriers. Renew. Sustain. Energy Rev. 2011, 15, 3780-3788. [CrossRef]

50. Kazem, H.A. Renewable energy in Oman: Status and future prospects. Renew. Sustain. Energy Rev. 2011, 15, 3465-3469. [CrossRef]

51. Al-Badi, A.H.; Albadi, M.H.; Al-Lawati, A.M.; Malik, A.S. Economic perspective of PV electricity in Oman. Energy 2011, 36, 226-232. [CrossRef]

52. Albadi, M.H.; Al-Hinai, A.S.; Al-Abri, N.N.; Al-Busafi, Y.H.; Al-Sadairi, R.S. Optimal allocation of solar PV systems in rural areas using genetic algorithms: A case study. Int. J. Sustain. Eng. 2013, 6, 301-306. [CrossRef]

53. Al Ghafri, A.H. Renewable energy in Oman Outlook. In Water E Energy; Public Authority for Electricity and Water: Muscat, Sultanate of Oman, 2014; pp. 1-34.

54. Alyahya, S.; Irfan, M.A. Analysis from the new solar radiation Atlas for Saudi Arabia. Sol. Energy 2016, 130, 116-127. [CrossRef]

55. Alawaji, S.H. Evaluation of solar energy research and its applications in Saudi Arabia-20 years of experience. Renew. Sustain. Energy Rev. 2001, 5, 59-77. [CrossRef]

56. Alawaji, S.H.; Hasnain, S.M. Role of Solar Energy Research in Transferring of Technology to Saudi Arabia. Energy Sources 1999, 21, 923-934. [CrossRef]

57. Almasoud, A.H.; Gandayh, H.M. Future of solar energy in Saudi Arabia. J. King Saud Univ.-Eng. Sci. 2015, 27, 153-157. [CrossRef]

58. Almarshoud, A.F. Performance of solar resources in Saudi Arabia. Renew. Sustain. Energy Rev. 2016, 66, 694-701. [CrossRef]

59. Alyahya, S.; Irfan, M.A. The techno-economic potential of Saudi Arabia's solar industry. Renew. Sustain. Energy Rev. 2015, 55, 697-702. [CrossRef]

60. Desert Solar Saudi Arabia. Top 10-Solar Projects KSA. Available online: http:/ / desertsolarsaudiarabia. com/top-10-solar-projects-ksa/\#kapsractwo (accessed on 22 November 2017).

61. Hayter, S.J.; Kandt, A.; Alicen Kandt, F. Renewable Energy Applications for Existing Buildings: Preprint. In 48th AiCARR International Conference; National Renewable Energy Laboratory (NREL): Baveno-Lago Maggiore, Italy, 2011; pp. 1-15.

62. Baljit, S.S.S.; Chan, H.-Y.; Sopian, K. Review of building integrated applications of photovoltaic and solar thermal systems. J. Clean. Prod. 2016, 137, 677-689. [CrossRef]

63. Zhang, X.; Shen, J.; Tang, L.; Yang, T.; Xia, L.; Hong, Z.; Wang, L.; Wu, Y.; Shi, Y.; Xu, P. Fundamentals of Renewable Energy and Applications Building Integrated Solar Thermal (BIST) Technologies and Their Applications: A Review of Structural Design and Architectural Integration. Fundam. Renew. Energy Appl. 2015, 5, 1-21. [CrossRef]

64. Zhai, X.Q.; Song, Z.P.; Wang, R.Z. A review for the applications of solar chimneys in buildings. Renew. Sustain. Energy Rev. 2011, 15, 3757-3767. [CrossRef]

65. Maerefat, M.; Haghighi, A.P. Passive cooling of buildings by using integrated earth to air heat exchanger and solar chimney. Renew. Energy 2010, 35, 2316-2324. [CrossRef]

66. Gastli, A.; Armendariz, J.S.M. Challenges facing grid integration of renewable energy in the GCC region. In EU-GCC Renewable Energy Policy Experts' Workshop; Gulf Research Center: Abu Dhabi, UAE, 2013; pp. 1-20.

67. Gastli, A.; Charabi, Y. Solar water heating initiative in Oman energy saving and carbon credits. Renew. Sustain. Energy Rev. 2011, 15, 1851-1856. [CrossRef]

68. Khatib, T.; Kazem, H.; Sopian, K.; Buttinger, F.; Elmenreich, W.; Albusaidi, A.S. Effect of Dust Deposition on the Performance of Multi-Crystalline Photovoltaic Modules Based on Experimental Measurements. Int. J. Renew. Energy Res. 2013, 3, 850-853.

69. Baras, A.; Bamhair, W.; Alkhoshi, Y.; Alodan, M.; Engel-Cox, J. Opportunities and challenges of solar energy in Saudi Arabia. In Proceedings of the World Renewable Energy Forum, Denver, CO, USA, 13-17 May 2012; pp. 1-6. 
70. Nepal, R.; Lawrence, C.; Tooraj, J.; Anupama, S. Small Systems, Big Targets: Power Sector Reforms and Renewable Energy Development in Small Electricity Systems. In IEB Working Paper No 1720; University of Cambridge: Cambridge, UK, 2017.

71. Griffiths, S.; Mills, R. Potential of rooftop solar photovoltaics in the energy system evolution of the United Arab Emirates. Energy Strateg. Rev. 2016, 9, 1-7. [CrossRef]

72. Jacobs, D.; Sovacool, B.K. Feed-In Tariffs and Other Support Mechanisms for Solar PV Promotion. In Comprehensive Renewable Energy; Sayigh, A., Ed.; Elsevier: Oxford, UK, 2012; pp. 73-109, ISBN 978-0-08-087873-7. article distributed under the terms and conditions of the Creative Commons Attribution (CC BY) license (http:/ / creativecommons.org/licenses/by/4.0/). 